\title{
Promotion of maize growth by a yellow morel, Morchella crassipes
}

\author{
Phonepaserd Phanpadith ${ }^{1}$ (D) Zhongdong $\mathrm{Yu}^{1} \cdot$ Dan $\mathrm{Yu}^{1} \cdot$ Sitthixay Phongsavath ${ }^{1} \cdot$ Kuocheng Shen $^{1} \cdot$ Wei Zheng $^{1}$. \\ Buangurn Phommakoun ${ }^{1}$
}

Received: 12 April 2019 / Accepted: 2 October 2019/Published online: 21 November 2019

(C) The Author(s) 2019

\begin{abstract}
Fungal species of morel (genus Morchella) have recently been found to form a symbiotic relationship with grasses. Our previous study documented that M. crassipes from Shaanxi, northwest China, increased growth of sweet corn Zea mays var. saccharata and suppressed Fusarium infections. In the present study, we examined the effect of M. crassipes inoculation on dent corn, Zea mays var. indentata cv. Plant growth response indexes and variables and soil variables were used to demonstrate how $M$. crassipes inoculation stimulates maize growth. Three suspensions of $M$. crassipes mycelium $(50,100,150 \mathrm{~mL})$ were inoculated into Zea may var. indentata. The results showed that M. crassipes inoculation significantly affected growth of all the inoculated maize plants and influenced some variables and indexes that are related to tissue specificity and dose dependence. Soil moisture, available $\mathrm{K}$ and $\mathrm{P}$ accumulation by $M$. crassipes were affected in inoculated plants and resulted in growth enhancements that were equal to that of the plants treated with urea. Our findings reveal that inoculation with $M$. crassipes had a positive effect on maize yield, making the crop system more sustainable. Thus $M$. crassipes has the potential to become a supplement or an alternative to urea fertilizers.
\end{abstract}

Keywords Sweetcorn (Zea mays var. saccharata) $\cdot$ M. crassipes (yellow morel) $\cdot$ Nutrients · Soil moisture $\cdot$ Antioxidant enzyme activities (SOD $\cdot$ CAT $\cdot$ POD $\cdot$ PAL)

\section{Introduction}

Plants are globally diverse, with approximately 500,000 species globally (Corlett 2016). Fungi that can form symbiotic relationship with plants are even more abundant and estimated at 1.5 million (Hawksworth 2001). A proportion of these fungi are not pathogens but promoters of plant growth (Castro et al. 2009). Some promote growth by producing growth hormones or suppressing the infection of fungal species like Fusarium verticillioides (Yu et al. 2016). Others improve water and nutrient relations (Asrar et al. 2012). Mutualism involves exchanges that benefits both partners in the symbiosis. Nutrient exchanges, for example, have been demonstrated for many mycorrhizal fungi (Jakobsen et al. 1992; Kheyrodin 2014), and other symbiosis as endophytes result

Zhongdong Yu

yuzhongdong001@nwsuaf.edu.cn

1 Department of Forest Protection, College of Forestry, Northwest A\&F University, No 3 Taicheng Road, Yangling 712100, Shaanxi, China in improved root biomass and root branching (Bossuyt et al. 2001; Denef et al. 2001; Harman and Uphoff 2019).

Species of Morchella (family Morchellaceae, order Pezizales, Phylum Ascomycota), commonly called morels, are among the most recognized edible mushrooms (Baynes et al. 2012). Morchella spp. have been documented to form mycorrhizae with trees (Dahlstrom et al. 2000; Rossbach et al. 2017) but they can also be saprotrophs (Liu et al. 2017). It has also been shown that Morchella spp. can form endophytic relationships with an invasive grass, Bromus tectorum (Baynes et al. 2012). Studies show that inoculation with Morchella elata improves the growth of B. tectorum and its fecundity (seed yield per plant). Inoculation experiments have shown that it is possible to promote growth and pathogen defense in commercial crops such as Zea mays var. saccharata, or sweet corn (Yu et al. 2016). Inoculation with $M$. crassipes improves maize plant height, biomass, and root development and suppresses $F$. verticillioides infection in mature corn ears, which can be attributed to phytohormones SA, ABA and IAA secreted by M. crassipes (Yu et al. 2016; Yu et al. 2017).

The objective of the present study was to examine the possible symbiotic relationship between $M$. crassipes and dent corn, Zea mays var. indentata. cv. 'Shaandan 985, which is widely grown in the Shaanxi Province (China). 


\section{Materials and methods}

\subsection{Soil sample and mycelium suspension preparation}

Soil was purchased from Xintiandi Organic Farm Co. Ltd., Yangling, China, which contained organic material $>50 \%$, sapropel $>20 \%$, glimmerite $>20 \%$, at $\mathrm{pH}$ 5.5-6.5 with low moisture content. Soil was autoclaved at $121{ }^{\circ} \mathrm{C}$ for $40 \mathrm{~min}$ before being used to fill pots.

Two-week old mycelium (with sclerotia) of M. crassipes, grown on potato dextrose agar medium (PDA), was scraped down and immediately suspended in $100 \mathrm{ml}$ sterilized deionized water per dish. Mycelia biomass was approximately $1 \mathrm{~g}$ per dish (Yu et al. 2016), which contains nitrogen 4.6\%, phosphorus $1.38 \%$, potassium $3.51 \%$, and carbon $37.1 \%$ (Rossbach et al. 2017). The Morchella mycelium suspension (MMS) was then applied to plant pots 2 times in the first 20 days of seedling growth.

\subsection{Experimental design and inoculation}

Plant pots $(10 \mathrm{~cm} \times 15 \mathrm{~cm}$ size $)$ were filled almost full of autoclaved soil samples. The experiments had five treatments: control (CK), urea solution and three different volumes of Morchella inoculum (50-, 100- and 150-ml MMS). Each treatment had five replicates and each experiment was repeated three times for a total of 75 pots. Maize seeds(Zea mays var. indentata cv 'Shaandan 985') were incubated in wet-cheese cloths at $25^{\circ} \mathrm{C}$ for $40 \mathrm{~h}$. Germinating seeds were then carefully placed in plant pots ( 5 seeds per pot). $100 \mathrm{ml}$ deionized water was added for control treatments; $100 \mathrm{ml}$ solution of 100 ppm urea was added for urea treatments; and MMS was added for inoculation treatments. After one week of growth, the tallest seedling was kept while the others were removed. Plants were watered every 4 days. Urea solution and MMS were added to plant pots three times on 1st day, 15th day and 30th day during the experiment period. Experiments were performed in a greenhouse at $30 / 20{ }^{\circ} \mathrm{C}$ (day/night) with an alternation of 10-h light and 14-h darkness.

\subsection{Root staining following inoculation}

After harvesting, root samples were randomly selected from each plant and washed in running tap water to remove particles of soil. They were cut into $1 \mathrm{~cm}$ sizes and transferred to $1.5 \mathrm{ml}$ centrifuge tubes for staining (Kiheri et al. 2017), softened by adding $1 \mathrm{ml}$ of $10 \% \mathrm{KOH}$ and subsequently heated to $90{ }^{\circ} \mathrm{C}$ for $40 \mathrm{~min}$ in a Thermostat Plus. After being washed in $10 \% \mathrm{H}_{2} \mathrm{O}_{2}$ and again in distilled water twice, the roots were acidified in 5\% KCL solution for $5 \mathrm{~min}$, followed by immersion in 2\% Trypan Blue for $10 \mathrm{~min}$. Specimens were examined in Lacto-phenol using an Olympus CX41 microscope.

\subsection{Measurement of plant growth promotion}

To assess the growth index, plant height was measured on the 7 th day and every four days thereafter for the remaining of the experimental period. The collar-leaf method (Nielsen 2003; Abendroth et al. 2011) was used to make the measurement of stem height. Stem diameter was measured twice for each plant at $10 \mathrm{~mm}$ above ground with a digital measuring device. The length and width of the latest visible collar leaf were measured to determine the leaf area. The width of leaf was measured at the widest point. Plants were harvested for biomass assessment after 50 days. Fresh weights of roots and shoots were separately noted and plants were dried at $70{ }^{\circ} \mathrm{C}$ for $50 \mathrm{~h}$.

\subsection{Plant elemental analyses ( N, P, K)}

Plant parts (i.e., roots, stems, and leaves) were washed, dried and ground. Extraction was performed with the $\mathrm{H}_{2} \mathrm{SO}_{4}$ and $30 \% \mathrm{H}_{2} \mathrm{O}_{2}$ digestion method (Idera et al. 2014). The digestion solution was used to determine the total nitrogen $(\mathrm{N})$, phosphorus $(\mathrm{P})$, and potassium $(\mathrm{K})$ contents. Total N, P, K of plant parts (root, stem, leaf) were analyzed separately, following the methods described by Chapman and Parker (1961) and Razi et al. (2011). Total $\mathrm{N}$ was determined using the Branne Luebbe Auto Analyzer 3 (AA3) system (Branne and Luebbe AA3, Norderstedt, Germany). Total P was determined with the Molybdenum Antimony Colorimetric Method by using a spectrophotometer (Adam et al. 2015). Total K was determined with $\mathrm{K}$ standard by using a flame photometer.

\subsection{Assessment of photosynthetic activity and chlorophyll}

Photosynthesis was measured in the greenhouse at $30^{\circ} \mathrm{C}$ on a sunny day by using the Li-6400 portable photosynthesis system (LI-COR Inc., Lincoln, NE, USA). Photosynthetic rates $\left(\mathrm{P}_{\mathrm{N}}\right)$, stomatal conductance (Gs), intercellular $\mathrm{CO}_{2}$ concentration $(\mathrm{Ci})$, and transpiration rates (Trmmo) were measured for each plant leaf and the measurement repeated four times. The light response curve was made with a $\mathrm{CO}_{2}$ flow rate at 500 $\mu \mathrm{molm} \mathrm{s}^{-1}$ and a PFD range of $0-1800 \mathrm{~m}^{-2} \mathrm{~s}^{-1}$ (Chang et al. 2017). For the chlorophyll content of maize leaves, a Konica Minolta Chlorophyll Meter (SPAD, Japan) was used on the 40th day (Khan et al. 2015; Ling et al. 2011). Each plant was measured 10 times on three recently-formed leaves.

\subsection{Assessment of antioxidant enzyme activities}

Extraction Maize leaves were collected on the 40th day and samples were immediately immersed in liquid nitrogen and stored at $-80{ }^{\circ} \mathrm{C}$. To obtain leaf extractions, 5-mg pieces of fresh leaf were cut and placed in tubes followed by addition of $300 \mu$ l extraction solution (containing 100 mM Tris, pH 7.4; 
150 mMNaCL; 1 mM EGTM; 1 mM EDTA; $1 \%$ Triton $\mathrm{x}-100$ and $0.5 \%$ sodium deoxycholate) and homogenized in an electric homogenizer at $4{ }^{\circ} \mathrm{c}$ for $2 \mathrm{~min}$. Inner walls of test tubes were washed twice with $300 \mu$ extraction solution. Test tubes were placed at $4{ }^{\circ} \mathrm{C}$ for $2 \mathrm{~h}$ in an orbital shaker and spun at $4{ }^{\circ} \mathrm{C}$ at $13000 \mathrm{x} g$ for $20 \mathrm{~min}$. Supernatants were transferred into new tubes and stored at $-80{ }^{\circ} \mathrm{C}$ for antioxidant enzyme assays.

Assay procedures Activities of antioxidant enzymes (Superoxide Dismutase (SOD), Catalase (CAT), Peroxidase (POD), Phenylalanine Ammonia-Lyase (PAL)) were measured using an ELISA assay according to the protocol by Gill \& Tuteja (2010): $10 \mu \mathrm{l}$ of sample extraction, $40 \mu \mathrm{l}$ of sample diluent and $100 \mu \mathrm{l}$ of horseradish peroxidase (HRPconjugate) reagents were added into each sample tube. Tubes were then incubated at $37^{\circ} \mathrm{C}$ for $60 \mathrm{~min}$ and washed five times with wash solution. Next, $50 \mu \mathrm{l}$ of Chromogen Solution A and B were separately added into sample tubes which were then shaken several times carefully. Samples were then incubated at $37^{\circ} \mathrm{C}$ for $15 \mathrm{~min}$ (samples were kept from light) and finally, $50 \mu \mathrm{l}$ of stop solution was added to tubes. When sample color changed from blue to yellow in a spectrophotometer, a standard curve was plotted and enzyme activities were calculated.

\subsection{Soil moisture and $\mathrm{pH}$ value}

One week before plant harvesting, plant pots were irrigated with $100 \mathrm{ml}$ deionized water. Five days later, soil moisture content was measured using a TDR 100/200 Soil Moisture Meter (Spectrum Tech. Inc., USA). Each plant pot was measured three times. $\mathrm{pH}\left(\mathrm{H}_{2} \mathrm{O}\right)$ value was measured according to procedures described by Adam et al. (2015): dried soil was ground, $0.2 \mathrm{~g}$ of dried soil was transferred to a beaker and $5 \mathrm{ml}$ of distilled water was added. The mixture was stirred every $10 \mathrm{~min}$ for one hour and then the $\mathrm{pH}$ value was measured with a Sartorius-PB 10, pH meter (Sartorius AG, Germany).

\subsection{Soil assessment of available $\mathrm{NO}_{3}{ }^{-}, \mathrm{NH}_{4}{ }^{+}, \mathrm{P}, \mathrm{K}$}

The effect of $M$. crassipes on essential macro-nutrients $(\mathrm{N}, \mathrm{P}, \mathrm{K})$ was analyzed. Sample soil from each pot was divided into subsamples. For available mineral nitrogen $\left(\mathrm{NO}_{3}{ }^{-}, \mathrm{NH}_{4}{ }^{+}\right)$measurement, fresh soil was collected and stored immediately at $4{ }^{\circ} \mathrm{C}$. For available $\mathrm{P}$ and $\mathrm{K}$ contents, soil was air dried for one month and ground. Measurements of N, P, K in soil were obtained, as per method in section 2.5 (following Adam et al. 2015).

\subsection{Statistical analysis}

Raw data was arranged in excel and all pairwise comparisons were tested for variability using Two-way ANOVAs and Tukey HSD's multiple comparisons tests. All analyses were conducted in IBM SPSS Statistic software, version 25. Mean differences were significant $(p<0.05)$.

\section{Results}

\subsection{Root staining following inoculation}

Confirmation of $M$. crassipes colonization of maize plant roots was demonstrated (Fig. 1). Hypha developed along with longitudinal axis of the maize roots (Fig. 1c), and intercellular hyphae of $M$. crassipes appeared in the epidermal cells, cortical cells and even pericyclic cells of maize roots (Figs. 1a and b). However, no hypha and colonization of non-M. crassipes were found in the maize roots (Fig. 1d). M. crassipes formed endophytic colonization in the roots of dent corn, as is in sweet corn roots (Yu et al. 2016).

\subsection{Effects of $M$. crassipes inoculation on plant growth}

Inoculation with $M$. crassipes had positive effects on maize plant (Table 1, Fig. 2). Fresh and dried biomasses of maize plants were substantially increased by the higher MMS volumes. Both the 100- and 150-MMS treatments increased green biomass when compared to the control (shoot: $p=$ $0.000, p=0.000$; root: $p=0.012, p=0.000$, respectively) and urea treatment (shoot: $p=0.015 ; p=0.000$; root: $p=$ $0.018, p=0.003$, respectively). For dry biomasses, both the 100- and 150-MMS treatment had promoted more growth than the control (shoot: $p=0.000, p=0.000$; root: $p=0.019$, $p=0.002$, respectively) and urea treatment (shoot: $p=0.024$; $p=0.001$; root: $p=0.036, p=0.015$, respectively). The 50 MMS treatment had a lesser impact on maize plant growth when compared to the control and urea treatments $(p<0.05)$. Effects on index of growth were similar to effects on biomass. The stem height of the plants inoculated with 100-MMS and 150-MMS were significantly improved when compared to controls $(p=0.000, p=0.004)$ and the stem height of 100 MMS inoculated plants was significantly improved as compared to urea treatment $(p=0.029)$ (Table 1). Stem diameters of the plants inoculated with 100- and 150-MMS on the 40th day were significantly improved as compared to the controls ( $p=0.011, p=0.012$ ). Leaf areas were sharply increased by 100- and 150-MMS inoculation compared to control $(p=$ $0.001, p=0.000)$ and urea treatments $(p=0.025, p=0.016)$. The density of the maize root systems was greater with increasing amount of Morchella inoculum. The crown root lengths of the plants inoculated with 50-, 100- and 150MMS were significantly increased when compared to the controls ( $p=0.033, p=0.004, p=0.004$, respectively) and only the crown root lengths of the plants inoculated with 100-MMS and 150-MMS were significantly improved as compared with urea treatment $(p=0.013, p=0.013)$ (Table 1). 
Fig. 1 Maize roots sections (40th day) stained with Trypan blue showing hyphae of $M$. crassipes, growing in air channels around cells (Figs: $1 \mathrm{a}$ and $\mathrm{b}$, cross sections, $1 \mathrm{c}$ longitudinal). Control root cells were devoid of colonization (Fig. 1d longitudinal section)

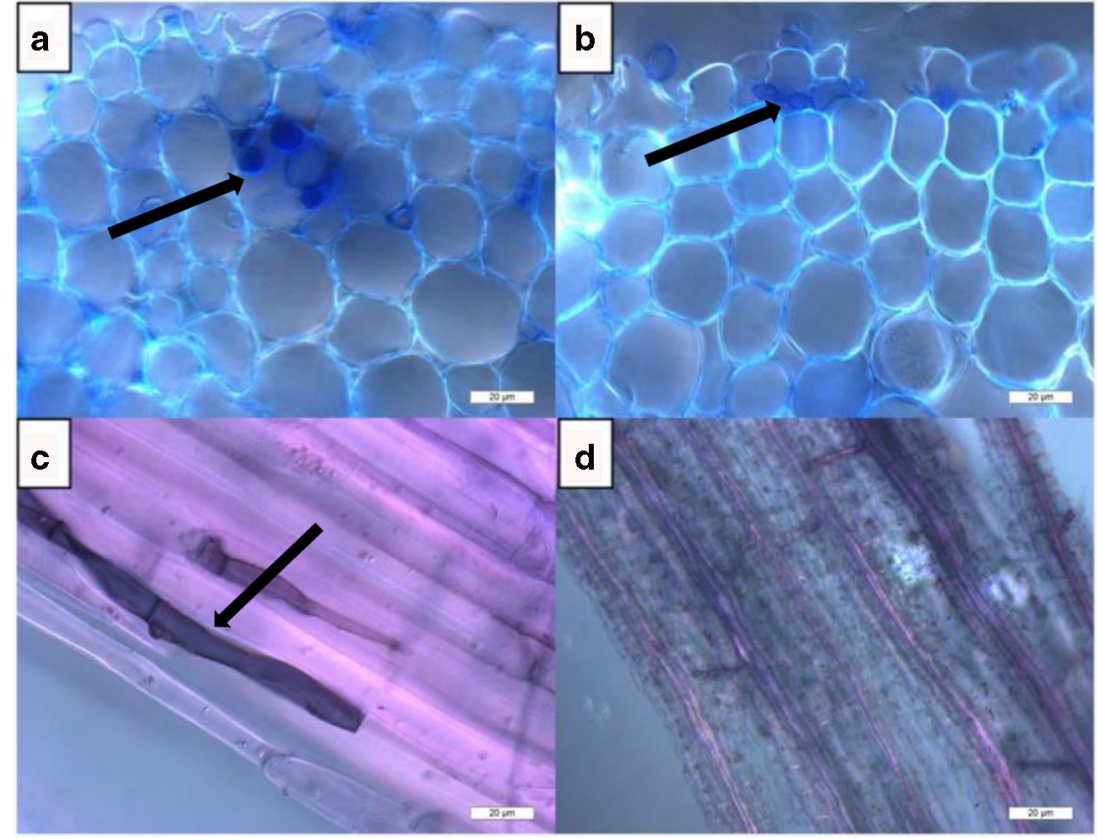

\subsection{Plant elemental analyses ( $N, P, K)$}

$\mathrm{N}$, P, and $\mathrm{K}$ contents in plant parts were assessed after inoculation with M. crassipes. For all the treatments with and without $M$. crassipes, the plants had highest $\mathrm{N}$ level in leaves, second highest $\mathrm{N}$ level in stems, and lowest $\mathrm{N}$ level in roots. The only exception found was that the $\mathrm{N}$ levels were higher in roots than in stems in the plants with the urea treatment. Potassium level in roots was found to be much lower than that in leaves and stems in all plants. The total $\mathrm{N}$ level in plants inoculated with $M$. crassipes was not significantly different from those in the control and urea-treated plants $(p>0.05)$. The same was true for the total $\mathrm{K}$ level in all the plants with treatments $(p>0.05)$. Increases in the total $\mathrm{P}$ content were seen in leaves of plants inoculated with the biggest volume of M. crassipes (Table 2).

\subsection{Assessment of photosynthesis and chlorophyll}

Both $M$. crassipes inoculation and urea treatment significantly increased the chlorophyll content in maize plant leaves when compared to control at $p=0.000$. However, the chlorophyll content in MMS-inoculated maize leaves was not significantly improved when compared to urea $(p>0.05)$ (Table 3$)$. Photosynthetic activities were not generally improved by M. crassipes inoculation treatments. A simple explanation is that $M$. crassipes inocula had no positive influence on the photosynthetic parameters. The only exception we found was that intercellular $\mathrm{CO}_{2}$ concentration $(\mathrm{Ci})$ in the plants treated with 50-MMS was higher than in 100- and 150-MMS treated plants (Table 3). It indicated that increasing amounts of MMS inocula had reduced photosynthetic activities.

\subsection{Assessment of antioxidant enzyme activities}

Antioxidant enzyme activities of maize leaf tissues on the 40th day indicated that activities of urea-treated plants were generally increased when compared with control (Figs. 3a-d). The M. crassipes inoculation showed positive effects on SOD activity in maize leaves. Increase of SOD activity in the MMStreated plants was significant at 270.11 Unit L $^{-1}, 318.72$ Unit $\mathrm{L}^{-1}, 342.57$ Unit $\mathrm{L}^{-1}$ of $50-, 100-, 150-\mathrm{MMS}$, respectively (Fig. 3a). The SOD activity registered higher in plants treated with more MMS inoculum. The SOD activity in 100- and 150-MMS inoculated maize leaves showed significant difference when compared to control at $p=0.000$. The PAL activity in leaves was enhanced in plants treated with low MMS volumes (Fig. 3b) and PAL activity tended to decrease in the plants with high MMS treatments. However, the plants treated with different amount of $M$. crassipes inocula showed significantly different level of increase in PAL activity in leaves compared to control $(p<0.05)$ but showed no significant change in PAL activity compared to the urea. CAT and PAL have similar antioxidant activities. A larger dose of MMS inocula may have less positive effect on their antioxidant activities in the plants as showed in (Fig. 3c). The POD activities in leaves were significantly decreased in the plants treated with increasing amount of MMS inocula as showed in Fig. $3 \mathrm{~d}$. An increase of POD activity was found in urea-treated plants and control.

\subsection{Soil assessment of available $\mathrm{NO}_{3}{ }^{-}, \mathrm{NH}_{4}{ }^{+}, \mathrm{P}, \mathrm{K}$}

M. crassipes inoculation improved the soil moisture as shown in Table 4. The water holding capacity (WHC) was positively 


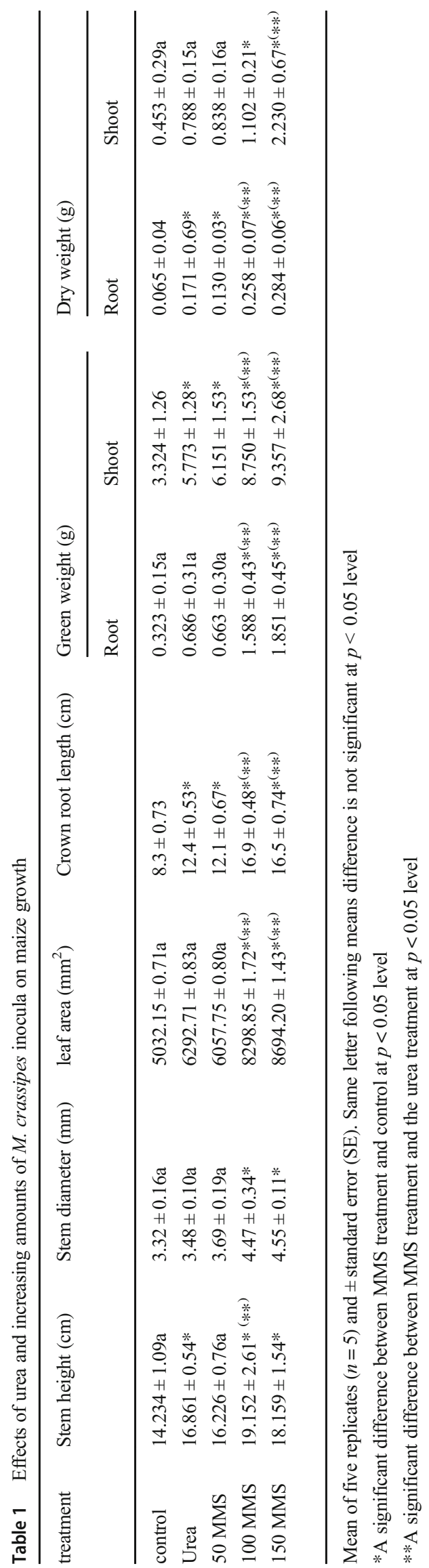




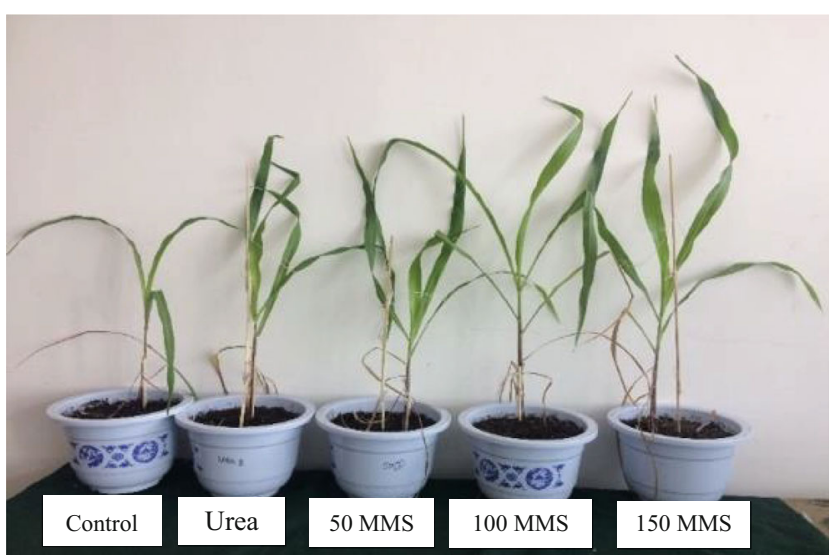

Fig. 2 Maize plant height

increased by higher amount of inocula (100- and 150MMS). Soil moisture in the pots with both 100 - and 150 -MMS treatments were significantly improved when compared to control $(p=0.009, p=0.012)$ but soil moisture in the pots treated with urea and 50-MMS showed no significant difference. Therefore, $M$. crassipes inoculation may have the potential to increase water-holding capacity and nutrient storage in soil. The $\mathrm{pH}\left(\mathrm{H}_{2} \mathrm{O}\right)$ was not significantly affected by $M$. crassipes inoculation (Table 4). A mean difference was not significant among all plants, which indicated $M$. crassipes had no effects on soil $\mathrm{pH}$ value during the short experimental period in a greenhouse, but $\mathrm{pH}$ values were higher in the $M$. crassipes-treated soil than in control.

Furthermore, this study has demonstrated M. crassipes inoculation improved available nutrients $\left(\mathrm{NH}_{4}{ }^{+}, \mathrm{NO}_{3}{ }^{-}, \mathrm{P}\right.$, $\mathrm{K}$ ) in soil as shown in Table 4 . The exchangeable $\mathrm{NH}_{4}{ }^{+}$was not affected significantly by MMS inoculation. According to the mean differences at $95 \%$, the $\mathrm{NH}_{4}{ }^{+}$content shows no difference in any treated plants. The lowest $\mathrm{NH}_{4}{ }^{+}$content is found in control at $7.221 \mathrm{mg} \mathrm{kg}^{-1}$ and the highest $\mathrm{NH}_{4}{ }^{+}$ content is found in the urea-treated soil at $8.62 \mathrm{mg} \mathrm{kg}^{-1}$. The exchangeable $\mathrm{NO}_{3}{ }^{-}$is increased in both the urea and the MMS-treated plants. As indicated by the mean difference analyses $(p<0.05)$, the $\mathrm{NO}_{3}{ }^{-}$content in 100 -MMS and ureatreated plants show significant improvement when compared to control $(p=0.021, p=0.032)$. Exchangeable $\mathrm{P}$ is not affected by $M$. crassipes inoculations, but available $\mathrm{P}$ in soil is decreased over time (Tables 2 and 4). In contrast, the exchangeable $\mathrm{P}$ in the control plants is higher than in other treated plants (Table 4). The exchangeable $\mathrm{K}$ is positively increased by increasing amounts of MMS inocula (Table 4), and the mean difference for exchangeable $\mathrm{K}$ in inoculated soils is significant when compared to both the urea and control treatments $(p=0.000, p=0.001)$.

Table 2 Plant element analyses (N, P, K)

\begin{tabular}{|c|c|c|c|c|c|c|c|c|c|}
\hline \multirow[t]{2}{*}{ Treatments } & \multicolumn{3}{|c|}{ Nitrogen $(\mathrm{N})\left(\mathrm{mg} \mathrm{kg}^{-1}\right)$} & \multicolumn{3}{|c|}{ Phosphorus (P) (mg kg $\left.{ }^{-1}\right)$} & \multicolumn{3}{|c|}{ Potassium (K) $\left(\mathrm{mg} \mathrm{kg}^{-1}\right)$} \\
\hline & Root & Stem & Leaf & Root & Stem & Leaf & Root & Stem & Leaf \\
\hline Control & $46.67 \pm 0.42 \mathrm{a}$ & $50.14 \pm 1.88 \mathrm{a}$ & $53.78 \pm 0.92 \mathrm{a}$ & $2.96 \pm 0.35 \mathrm{a}$ & $2.71 \pm 0.14 \mathrm{a}$ & $2.589 \pm 0.13 b$ & $5.73 \pm 0.48 \mathrm{a}$ & $11.88 \pm 1.17 \mathrm{a}$ & $14.14 \pm 1.26 \mathrm{a}$ \\
\hline Urea & $46.91 \pm 0.89 \mathrm{a}$ & $43.21 \pm 2.88 b$ & $55.35 \pm 0.49 \mathrm{a}$ & $2.41 \pm 0.69 \mathrm{~b}$ & $2.57 \pm 0.49 \mathrm{a}$ & $2.60 \pm 0.37 b$ & $4.24 \pm 1.47 \mathrm{~b}$ & $10.52 \pm 1.70 \mathrm{~b}$ & $12.22 \pm 1.39 b$ \\
\hline $50 \mathrm{MMS}$ & $44.78 \pm 0.44 \mathrm{a}$ & $46.58 \pm 1.15 \mathrm{a}$ & $55.51 \pm 1.09 \mathrm{a}$ & $2.77 \pm 0.77 \mathrm{a}$ & $3.01 \pm 0.22 \mathrm{a}$ & $3.06 \pm 0.41 \mathrm{a}$ & $5.34 \pm 0.30 \mathrm{a}$ & $10.97 \pm 1.14 \mathrm{ab}$ & $12.25 \pm 1.31 \mathrm{~b}$ \\
\hline $100 \mathrm{MMS}$ & $45.85 \pm 0.58 \mathrm{a}$ & $47.34 \pm 1.33 a$ & $55.02 \pm 1.18 \mathrm{a}$ & $3.11 \pm 0.29 \mathrm{a}$ & $3.00 \pm 0.46 \mathrm{a}$ & $3.08 \pm 0.42 \mathrm{a}$ & $5.24 \pm 0.61 \mathrm{a}$ & $11.57 \pm 1.07 \mathrm{a}$ & $13.66 \pm 1.08 \mathrm{a}$ \\
\hline $150 \mathrm{MMS}$ & $44.09 \pm 0.73 a$ & $49.58 \pm 3.8 \mathrm{a}$ & $54.58 \pm 1.13 \mathrm{a}$ & $3.24 \pm 0.20 \mathrm{a}$ & $3.15 \pm 0.22 \mathrm{a}$ & $3.28 \pm 0.29 \mathrm{a}$ & $4.93 \pm 0.40 \mathrm{a}$ & $11.51 \pm 1.01 \mathrm{a}$ & $12.28 \pm 1.36 \mathrm{~b}$ \\
\hline
\end{tabular}

Mean of five replicates $(n=5)$ and \pm standard error (SE)

Same letter following means difference is not significant at $P<0.05$ level

Table 3 Assessment of photosynthesis and chlorophyll

\begin{tabular}{llllll}
\hline Treatments & phot $\left(\mu \mathrm{mol} \mathrm{CO} \mathrm{m}^{-2} \mathrm{~s}^{-1}\right)$ & $\mathrm{Gs}\left(\mathrm{mol} \mathrm{H} \mathrm{O} \mathrm{m}^{-2} \mathrm{~s}^{-1}\right)$ & $\mathrm{Ci}\left(\mu \mathrm{mol} \mathrm{CO} \mathrm{emol}^{-1}\right)$ & ${\text { Trmmo }\left(\mathrm{mmol} \mathrm{H}_{2} \mathrm{O} \mathrm{m} \mathrm{s}^{-2}\right)}_{\mathrm{C}^{-1}} \mathrm{Chlorophyll}$ \\
\hline Control & $9.28 \pm 0.455 \mathrm{a}$ & $0.069 \pm 0.003 \mathrm{a}$ & $214 \pm 12.42 \mathrm{a}$ & $2.650 \pm 0.092 \mathrm{a}$ & $31.223 \pm 2.39$ \\
Urea & $9.592 \pm 0.516 \mathrm{a}$ & $0.073 \pm 0.009 \mathrm{a}$ & $183 \pm 8.105 \mathrm{a}$ & $2.536 \pm 0.274 \mathrm{a}$ & $37.837 \pm 2.25^{*}$ \\
$50 \mathrm{MMS}$ & $9.76 \pm 0.261 \mathrm{a}$ & $0.075 \pm 0.005 \mathrm{a}$ & $243 \pm 17.491^{(* *)}$ & $3.230 \pm 0.255 \mathrm{a}$ & $36.055 \pm 2.19^{*}$ \\
$100 \mathrm{MMS}$ & $11.42 \pm 1.389 \mathrm{a}$ & $0.079 \pm 0.011 \mathrm{a}$ & $178 \pm 17.869 \mathrm{a}$ & $2.824 \pm 0.419 \mathrm{a}$ & $37.316 \pm 1.36^{*}$ \\
$150 \mathrm{MMS}$ & $11.72 \pm 0.565 \mathrm{a}$ & $0.072 \pm 0.004 \mathrm{a}$ & $191 \pm 19.732 \mathrm{a}$ & $3.080 \pm 0.180 \mathrm{a}$ & $38.582 \pm 1.29^{*}$ \\
\hline
\end{tabular}

Mean of five replicates $(\mathrm{n}=5)$ and \pm standard error $(\mathrm{SE})$. Same letter following means difference is not significant at $p<0.05$ level

*A significant difference between MMS treatment and control at $p<0.05$ level

**A significant difference between MMS treatment and the urea treatment at $p<0.05$ level 

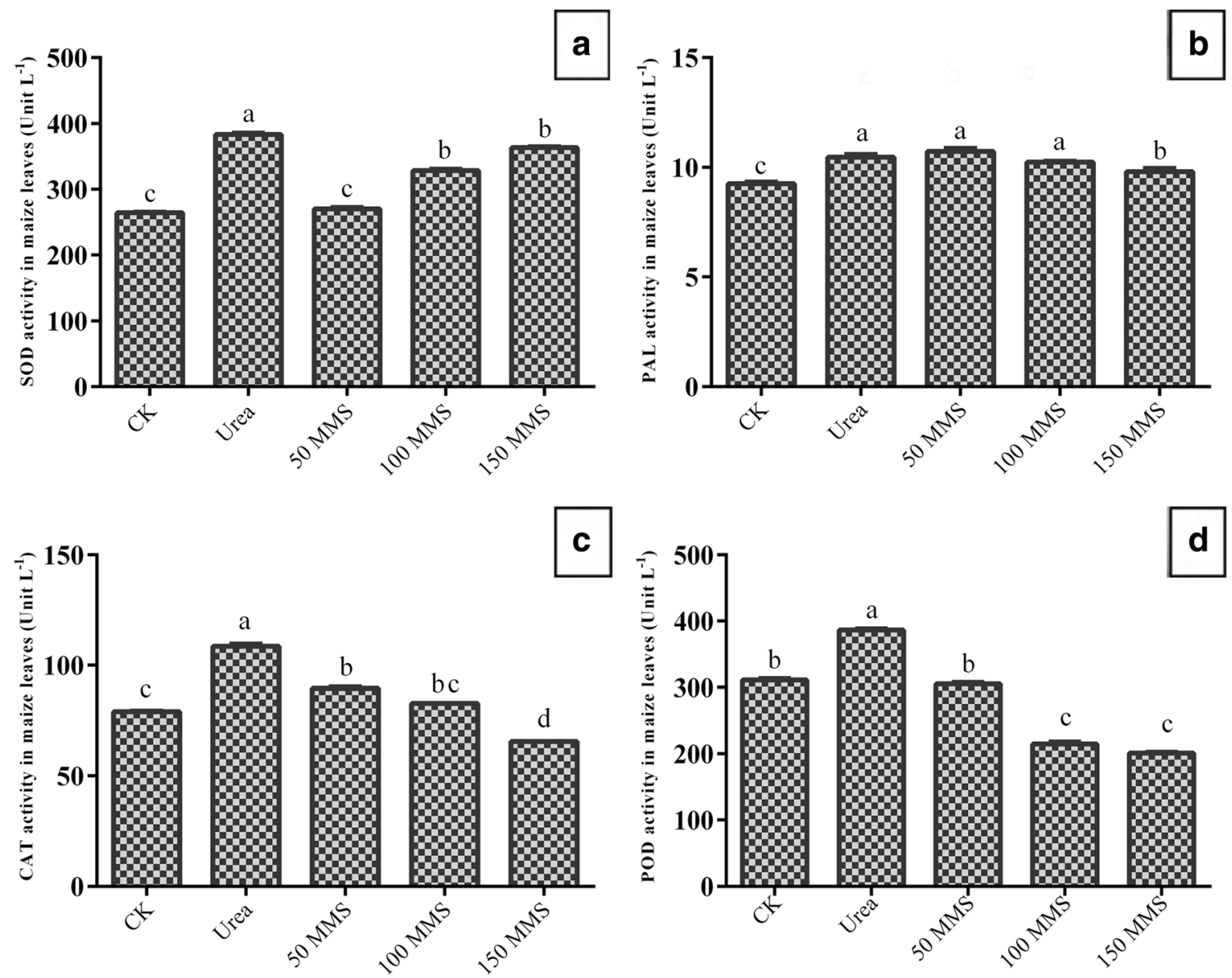

Fig. 3 Effects of urea and increasing volumes of $M$. crassipes on antioxidant enzyme activities in maize plants. (a) Superoxide dismutase (SOD) content, (b) Phenylalanine ammonia-lyase (PAL) content, (c)

Catalase (CAT) content, (d) Peroxidase (POD) content of maize plant leaf. Bars showing by the same letter are not significantly different at $p<0.05$ level

\section{Discussion}

Our findings support the positive effects of $M$. crassipes on maize plant production. The inoculation with $M$. crassipes successfully increases maize plant growth, biomass, plant height, crown root length and leaf area. It was clear that the 100- and 150 -MMS treatments significantly enhanced maize plant growth (Table 1), similarly to the findings of Yu et al. (2016)

who tested a different corn cultivar in a greenhouse setting with the same Morchella isolate. Baynes (2012) has also reported that $M$. elata complex improves growth and fecundity (i.e., seed yield per plant) of $B$. tectorum. Mycelium of $M$. crassipes colonizes the root and forms an ectendomycorrhizal-like symbiosis with dent corn, similar to sweet corn.

Urea as a fertilizer is widely used in agricultural systems around the world, and is usually not efficiently used. Cereals

Table 4 Chemical and physical characterizations of soil

\begin{tabular}{|c|c|c|c|c|c|c|}
\hline Treatments & $\mathrm{NO}_{3}^{-}\left(\mathrm{mg} \mathrm{kg}^{-1}\right)$ & $\mathrm{NH}_{4}^{+}\left(\mathrm{mg} \mathrm{kg}^{-1}\right)$ & $\mathrm{K}\left(\mathrm{mg} \mathrm{kg}^{-1}\right)$ & $\mathrm{P}\left(\mathrm{mg} \mathrm{kg}^{-1}\right)$ & soil Moisture & $\mathrm{pH}$ \\
\hline Control & $7.703 \pm 2.09 \mathrm{a}$ & $7.221 \pm 0.41 \mathrm{a}$ & $16.706 \pm 0.46 \mathrm{a}$ & $2.794 \pm 1.41 \mathrm{a}$ & $10.88 \pm 1.08 \mathrm{a}$ & $4.17 \pm 0.05 \mathrm{a}$ \\
\hline Urea & $13.339 \pm 3.28^{*}$ & $8.621 \pm 0.13 a$ & $20.301 \pm 2.01 \mathrm{a}$ & $1.986 \pm 0.95 \mathrm{a}$ & $12.91 \pm 0.48 \mathrm{a}$ & $4.28 \pm 0.08 \mathrm{a}$ \\
\hline $50 \mathrm{MMS}$ & $8.930 \pm 3.31 \mathrm{a}$ & $8.531 \pm 0.29 \mathrm{a}$ & $25.454 \pm 1.45 *(* *)$ & $1.284 \pm 0.31 \mathrm{a}$ & $11.32 \pm 0.76 \mathrm{a}$ & $5.54 \pm 0.06 \mathrm{a}$ \\
\hline $100 \mathrm{MMS}$ & $12.935 \pm 1.61 *$ & $8.249 \pm 0.18 \mathrm{a}$ & $26.824 \pm 2.07 *(* *)$ & $1.758 \pm 0.51 \mathrm{a}$ & $17.71 \pm 1.38 *$ & $5.40 \pm 0.02 \mathrm{a}$ \\
\hline $150 \mathrm{MMS}$ & $9.793 \pm 1.95 \mathrm{a}$ & $5.591 \pm 0.29 \mathrm{a}$ & $28.472 \pm 3.04 *(* *)$ & $1.964 \pm 0.57 \mathrm{a}$ & $16.53 \pm 1.26^{*}$ & $5.43 \pm 0.04 a$ \\
\hline
\end{tabular}

Mean of five replicates $(\mathrm{n}=5)$ and \pm standard error (SE). Same letter following means difference is not significant at $p<0.05$ level

*A significant difference between MMS treatment and control at $p<0.05$ level

**A significant difference between MMS treatment and the urea treatment at $p<0.05$ level 
can take up to $20 \%$ to $50 \%$ of $\mathrm{N}$ of urea. A large proportion of $\mathrm{N}$ that does not get uptaken by the crop can create environmental problems, such as eutrophication of surface waters. The impact on human health remains controversial (Mosier et al. 2005). In contrast, $M$. crassipes inoculation has the potential to be a supplement or an alternative to urea application. The total $\mathrm{P}$ accumulation in $M$. crassipes-treated plants was equal to that in urea-treated plants. The results show that available $\mathrm{P}$ was decreased in MMS-inoculated pots but that the total $\mathrm{P}$ accumulations in plants treated with $150-\mathrm{MMS}$ was significantly greater than in plants treated with 50- and 100-MMS (Table 2). Under limiting conditions, the mycelium of $M$. crassipes may help plant roots absorb soil P. Although inoculation with M. crassipes suspensions has no effects on $\mathrm{N}$ and $\mathrm{K}$ uptake in maize plant, the availability of soil $\mathrm{N}$ and $\mathrm{K}$ are enhanced by MMS inocula; $\mathrm{N}$ and $\mathrm{K}$ are redistributed in plant organs and their levels are highest in leaves, and lowest in roots (Table 2). The available $\mathrm{K}$ concentration was increased because $M$. crassipes inoculation may help $\mathrm{K}$ dissolve from glimmerite in the tested soil (Table 4, Kheyrodin 2014), which helps root development and nutrient absorption in dent corn.

The key factors influencing photosynthetic parameters were light, temperature, and position in a greenhouse and chlorophyll level in maize leaves (Wang et al. 2017). Inoculated maize plants grew well, and had significantly higher level of chlorophyll (Pinior et al. 2005; Fan and Liu 2011; Zhang et al. 2018). This improves energy absorbance and photosynthetic activity at early plant growth stages (Heinonsalo et al. 2012). M. crassipes inoculation also had positive effects on the SOD, CAT and PAL enzyme activities as shown in Fig. 3a, and these antioxidant enzymes in MMStreated plants work as ROS scavengers more actively than in the urea-treated plants (Gill and Tuteja 2010; MacDonald and D'Cunha 2007).

Soil moisture increased due to receiving more Morchella inoculum. It seems that the extraradical mycelium of the fungus is capable of retaining more water compared with controls. An increase in soil moisture content is beneficial for photosynthetic activity and soil nutrient uptake (Slatyer 1967; Kozlowski 1968; Richard 1970; Nadeem et al. 2014). M. crassipes had no significant effects on the $\mathrm{pH}$ of soil for the short experimental period but $\mathrm{pH}$ value goes up with added M. crassipes inoculum, as is found in other fungi ( $\mathrm{Li}$ et al. 1991; Mashela 2002). Morchella may change the capacity of $\mathrm{K}^{+}$and $\mathrm{Na}^{+}$absorption in maize which could lead to a change of pH (Martinez et al. 2004), but the cause remains unknown.

In conclusion, $M$. crasssipes inoculation increases growth without increasing plant stress which is reflected by antioxidant enzyme (SOD, CAT, PAL, and POD) activities. It is clear that M. crassipes and perhaps other species of Morchella sp. promote growth of maize. It is potentially a greener, safer, and more sustainable bio-fertilizer that can be used as an alternative to urea in farming.
Acknowledgements This study was supported by the National Key Research Projects (2017YFD0600103-4-2) and National Key Technology Support Program (2015BAD22B04) in China. Our appreciation goes to Prof. Dr. George Newcombe who gave important suggestions after reviewing this manuscript. Thanks also go to Chinese Govt. Scholarship Council for funding this study.

Open Access This article is distributed under the terms of the Creative Commons Attribution 4.0 International License (http:// creativecommons.org/licenses/by/4.0/), which permits unrestricted use, distribution, and reproduction in any medium, provided you give appropriate credit to the original author(s) and the source, provide a link to the Creative Commons license, and indicate if changes were made.

\section{References}

Abendroth LJ, Elmore RW, Boyer MJ, Marlay SK (2011) Corn growth and development. Iowa State Univ. Extension Publication PMR1009. https://store.extension.iastate.edu/Product/CornGrowth-and-Develo pment. Accessed July 2016

Adam AHM, Abdalla IMF, Abdelkreim M, Ibrahim GA (2015) Analysis of soil NPK, $\mathrm{pH}$ and electrical conductivity at Adham Area-Renk, Upper Nile State. Int J Sci Techn 12:341-347

Asrar AA, Fattah GMA, Elhindi KM (2012) Improving growth, flower yield, and water relations of snapdragon (Antirhinum majus L.) plants grown under well-watered and water-stress conditions using arbuscular mycorrhizal fungi. Photosynthetica 50:305-316. https:// doi.org/10.1007/s11099-012-0024-8

Bossuyt H, Denef K, Six J, Frey SD, Merckx R, Paustian K (2001) Influence of microbial populations and residue quality on aggregate stability. Appl Soil Ecol 16:195-208

Baynes M, Newcombe G, Dixon L, Castlebury L, O’Donnell K (2012) A novel plant-fungal mutualism associated with fire. Fungal Biology 116:133-144

Chang TG, Xin CP, Qu MZ, Zhao HL, Song QF, Zhu XG (2017) Evaluation of protocols for measuring leaf photosynthetic properties of field-grown rice. Rice Sci 24:1-9

Corlett RT (2016) Plant diversity in a changing world: status, trends, and conservation needs. Plant Diver 38:10-16

Chapman HD, Parker F (1961) Determination of NPK method of analysis for soil, plant and water. Division of Agricultural sciences, University of California, pp 150-179

Castro RO, Cornejo HAC, Rodríguez M, Bucio JL (2009) The role of microbial signals in plant growth and development. Plant Signal Behav 8:701-712

Denef K, Six J, Bossuyt H, Frey SD, Elliott ET, Merckx R, Paustian K (2001) Influence of dry-wet cycles on the interrelationship between aggregate, particulate organic matter, and microbial community dynamics. Soil biol Biochem 33:1599-1611 https://doi.orghttps://doi. org/10.1016/S0038-0717(01)00076-1

Dahlstrom JL, Smith JE, Weber NS (2000) Mycorrhiza-like interaction by Morchella with species of the Pinaceae in pure culture synthesis. Mycorrhiza 9:279-285. https://doi.org/10.1007/PL00009992

Fan QJ, Liu JH (2011) Colonization with arbuscular mycorrhizal fungus affects growth, drought tolerance and expression of stressresponsive genes in Poncirus trifoliata. Acta Physiol Plant 33:1533. https://doi.org/10.1007/s11738-011-0789-6

Gill SS, Tuteja N (2010) Reactive oxygen species and antioxidant machinery in abiotic stress tolerance in crop plants. Plant Physiol Biochem 48:9-30

Hawksworth DL (2001) The magnitude of fungal diversity: the 1.5 million species estimate revisited. Mycol Res 105:1422-1432

Heinonsalo J, Juurola E, Linden A, Pumpane J (2012) Ectomycorrhizal fungi affect scots pine photosynthesis through nitrogen and water 
economy, not only through increased carbon demand. Env Exp Bot 109:103-112. https://doi.org/10.1016/j.envexpbot.2014.08.008

Harman GE, Uphoff N (2019) Symbiotic root-endophytic soil microbes improve crop productivity and provide environmental benefits. Scientifica vol. 2019, article ID 9106395,25 pages, 2019. https:// doi.org/10.1155/2019/9106395

Idera F, Omotola O, Paul UJ, Adedayo A (2014) Evaluation of the effectiveness of different acid digestion on sediments. J Appl Chem 12: 39-47

Jakobsen I, Abbott LK, Robson AD (1992) External hyphae of vesiculararbuscular mycorrhizal fungi associated with Trifolium subterraneum L. spread of hyphae and phosphorus inflow into roots. New Phytol 120:371-380

Khan AR, Zhihui C, Ghazanfar B, Khan MA, Ahmad SS, Ahmad I (2015) Acetyl salicylic acid and 24-epibrassinolide attenuate decline in photosynthesis, chlorophyll contents and membrane thermostability in tomato (Lycopersicon esculentum mill.) under heat stress. Pak J Bot 47:63-70

Kozlowski TT (1968) Water deficits and plant growth, vol 1. Academic Press, New York, pp 137-193

Kiheri H, Heinonsalo J, Timonen S (2017) Staining and microscopy of mycorrhizal fungal colonization. Journal of Berry Research 7:231237. https://doi.org/10.3233/JBR-170160

Kheyrodin H (2014) Plant and soil relationship between fungi. Int J Res Studies Biosci 9:42-49

Ling Q, Huang W, Jarvis P (2011) Use of SPAD-502 meter to measure leaf chlorophyll concentration in Arabidopsis thaliana. Photosynth Res 107:209-214

Li XL, George E, Marschner H (1991) Phosphorus depletion and pH decrease at the root-soil and hyphae-soil interfaces of VA mycorrhizal white clover fertilized with ammonium. New Phytol 199:397-404

Liu QZ, Ma HS, Zhang Y, Dong CH (2017) Artificial cultivation of true morel: current state, issue and perspectives. Crit Rev Biotechnol 38: 1-13. https://doi.org/10.1080/07388551.2017.1333082

MacDonald MJ, D'Cunha GB (2007) A modern view of phenylalanine ammonia-lyase. Biochem Cell Biol 85:273-282. https://doi.org/10. 1139/O07-018

Martinez CR, Chanway CP, Albertini AVP, Figueiredo MVB, Sampaio AH, Castellon RR, Cavada BS, Lima-Filho JL (2004) The interaction of Vatairea macrocarca and Rhizobium tropici: net H+ efflux stimulus and alteration of extracellular $\mathrm{Na}+$ concentration. FEMS Microbiol Lett 238:17-22

Mashela PW (2002) Ground wild cucumber fruits suppress numbers of Meloidogyne incognita on tomato in microplots. Nematropica 32:13-19
Nadeem SA, Ahmad MS, Zahir ZA, Javaid A, Ashraf M (2014) The role of mycorrhizae and plant growth promoting rhizobacteria (PGPR) in improving crop productivity under stressful environments. Biotechn Adv 32:429-448. https://doi.org/10.1016/j.biotechadv.2013.12.005

Nielsen RL (2003) Determining corn leaf stages. Agronomy Dept., Purdue Univ. West Lafayette, IN 47907-2054. http://www. kingcorn.org/news/articles.03/LeafStaging-05 20.html. Accessed May 2004

Pinior A, Grunewaldt-Stöcker G, von Alten H, Strasser RJ (2005) Mycorrhizal impact on drought stress tolerance of rose plants probed by chlorophyll a fluorescence, proline content and visual scoring. Mycorrhiza 15:596-609. https://doi.org/10.1007/s00572-005-00011

Razi MFD, Khan IA IA, Jaskani MJ (2011) Citrus plant nutritional profile in relation to Huanglongbing prevalence in Pakistan. Pak J Agri Sci 48:209-304

Richard CS (1970) The effect of soil moisture and day temperature on photosynthesis, growth and needle anatomy of scotch pine seedlings. Retrospective Theses and Dissertations. 4358. https://lib.dr. iastate.edu/rtd/4358. Accessed July 2013

Rossbach M, Kummerle E, Schmidt S, Gohmert M, Stieghorst C, Revay Z, Wiehl N (2017) Elemental analysis of Morchella esculenta from Germany. J Radioanal Nucl Chem 313:273-278. https://doi.org/10. 1007/s10967-017-5298-7

Slatyer RO (1967) Plant-water relationships. Academic Press, New York, p 378

Wang J, Huang HJ, Jia S, Zhong XM, Li FG, Zhang KY, Shi ZS (2017) Photosynthesis and chlorophyll fluorescence reaction to difference shade stresses of weak light sensitive maize. Pak J Bot 49:16811688

Yu D, Bu FF, Hou JJ, Kang YX, Yu ZD (2016) A morel improved growth and suppressed Fusarium infection in sweet corn. World J Microb Biotechn 32:192. https://doi.org/10.1007/s11274-016-2151-z

Yu ZD, Phanpadith P, Zhang S, Yu D, Li ML, Kang YX (2017) Biocharmorel promotes wheat saline resistance by increasing root/shoot ratio. Fres Env Bull 26:52-58

Zhang T, Hu Y, Zhang K, Tian C, Guo J (2018) Arbuscular mycorrhizal fungi improve plant growth of Ricinus communis by altering photosynthetic properties and increasing pigments under drought and salt stress. Ind Crops Prod 117:13-19. https://doi.org/10.1016/j.indcrop. 2018.02.087

Publisher's note Springer Nature remains neutral with regard to jurisdictional claims in published maps and institutional affiliations. 